\title{
The International Congress of Anthropological and Ethnological Sciences
}

\begin{abstract}
$\triangle$ SESSION of the International Congress of A Anthropological and Ethnological Sciences took place in Copenhagen on July 31-August 6, and was followed by a two-day tour through parts of Denmark for members of the Congress who could spare the extra time required. Actually it was only the second time that this most newly fledged of congresses had met, and its great success testifies to the ever-growing interest throughout the world in the study of man, as well as to the immense trouble taken by the Danish organizers to see that everything should proceed smoothly and without any hitch. More than seven hundred members and associates were present, some 29 countries and 177 learned societies and institutions being represented.

The official opening meeting of the Congress did not take place until the afternoon of August 1, but already there had been a reception on the previous evening to enable members to meet one another. This was an excellent arrangement. After all, the main function of these international gatherings is not so much to facilitate the announcement of startling discoveries as to permit specialists from various countries to meet each other and discuss together their ideas and problems, the papers in general being little more than pegs upon which friendly, often almost informal, discussions can be hung. In this respect, the organization at Copenhagen was perfect. On several evenings there were after-dinner receptions in museums, etc., where innumerable discussions took place, helped by a liberal supply of Carlsberg beer and light refreshments !
\end{abstract}

The official opening ceremony was dignified by the presence of H.M. the King of Denmark, to whom delegates from several countries were presented. Inaugural ceremonies can easily become somewhat tedious functions: not so this one. His Majesty's presence testified to the importance of the occasion and, further, the proceedings were kept commendably short. Besides the necessary speeches of greeting from some of the national delegates and an oration from Dr. Thomas Thomsen, head of the Department of Ethnography in the National Museum and president of the Congress, there was a short orchestral symphony by Kunzen (1761-1817) which helped to lighten the proceedings. Later in the afternoon there was a motor-bus tour of the city.

On Tuesday morning, the work of the sections began and continued daily until the final closure on the Saturday afternoon, with the exception of Thursday, which was devoted to an all-day excursion. There were seven sections, a number of which were subdivided. From A to $\mathrm{G}$ they were severally concerned with physical anthropology and allied matters ; psychology ; demography ; ethnology ; ethnography, there being sub-sections dealing with Asia, Africa, America, Oceania, the Arctic and Europe; sociology and religion; linguistics and writing. Obviously it is not possible to discuss all the papers here; for that one must await the publication which will appear in due course. But mention can be made of one or two.

"What is a Human Race ?" was discussed in Section A by Dr. Nordenstreng of Uppsala, where, too, Dr. F. Weidenreich tabulated a "Classification of Fossil Hominids" definitely placing the existence of Homo sapiens in a period anterior to that of our well-known fossil remains of Homo primigenius. Questions of blood groups also came up for discussion in this section. In Section D (Ethnology) a paper by Prof. Hatt on the ownership of cultivated land in early times produced an interesting discussion, as also did those by Prof. Herskovitz on the economic surplus and its disposal and by Prof. Firth on the characteristics of a primitive economy. In this section, too, the problems of the development of primitive agriculture and of the horse in Neolithic times were dealt with by Dr. Miles and Dr. Gandert respectively, as well as the first cultivation of wheat and the spread of agriculture, by Mr. Harold Peake.

The sub-sections of Section $\mathrm{E}$ provided a wealth of papers. Perhaps one may mention especially those by Profs. Arik and Kansu on recent excavations and palæolithic discoveries in Turkey and by Sir Theodore Tasker on the archæological wealth of the State of Hyderabad, not that there were not many other papers of importance but because these three bore witness to the anthropological work that has recently been so successfully started in these distant regions. Among other British anthropologists present who read papers were Profs. Hutton and Daryll Forde and Dr. Lindgren. Any account of these sectional papers is, however, bound to be invidious at this stage, since the writer was only able to listen to a limited number and to gain information from his friends who had been to others.

A few joint meetings of various sections took place where slides and films were shown. Thus Dr. Morley demonstrated the results of twentyfive years of research in the Maya area of Middle America, while at another time ethnographical films were projected. A general meeting to see films of Greenland, Old and New, was arranged for one evening, and this was preceded by a talk from Mr. Daugaard-Jensen, the chief administrator in the country, who gave us an impressive account of what Denmark has done and is doing for the Greenlanders.

Throughout the period of the Congress, the National and other museums were open free of charge to members. The National Museum has been recently reconstructed and enormously enlarged. Not only are the prehistoric collections from Denmark and the immense series of Eskimo objects unique in the world, but also the arrangement of the Museum is most carefully thought out. It is not a mere storehouse of specimens : to follow the sequence of galleries is an educational experience. If only the British Museum could be rearranged in a like manner ! One evening, a reception was held at the Museum and the closing scene was really emotionally memorable. At 10.30 p.m. everyone assembled in the great courtyard, where there are model megalithic monuments in the open air. Then a museum showcase was opened and two great Bronze Age Lurer were taken out and handed to two trumpeters who, standing on some steps above the assembled members, proceeded to play stirring duets upon them. The effect was electric-were we not listening to instruments which had first been played more than 3000 years ago ?and it was enhanced by the knowledge that the performance can seldom be repeated, the authorities 
being justly fearful lest the vibration might shatter these ancient and beautiful trumpets.

The excursion on Thursday was to Elsinore and the Castle of Frederiksborg. At the former place, in the great hall of Hamlet's Castle, a lecture on "Natural Philosophy and Human Culture" was delivered by the distinguished physicist Prof. Niels Bohr. The municipality of Marienlyst, a seaside resort close to Elsinore, most kindly provided a lunch which was preceded by a display of water acrobatics by Green. landers in their kyaks: and an astonishing display it was. On the last evening, members dropped their science and became ordinary human beings. After a really sumptuous dinner chez Nimb they either danced or passed into the Tivoli (Copenhagen's White City), where the learned were seen happily smashing plates at 5 shies for $6 d$. or careering madly down the scenic railway-of such is a true League of Nations !

In conclusion, unstinted praise must once again be given to the organizing committee, and in this connexion the name of Dr. Birket-Smith must especially be mentioned. He was always helpful and always at hand. Everything worked splendidly, and anyone who has ever had to 'organize' more than 700 people on excursions, at lectures, for entertainments and meals will realize what this means. Nor did the considera- tion of our Danish hosts confine itself to the full members alone. As always, a number of associates, wives of members and others, were present who might perhaps be expected to be less interested in attending religiously the meetings of the sections, and for these people special activities, including a ladies' lunch at the Yacht Club, were arranged by a ladies' committee. Parties, for example, visited the porcelain works and the not less famous Georg Jensen silver works. There is no doubt that everyone worked very hard to make the Congress the success it was, and certainly their labours were much appreciated. Fortunately, the opportunity occurred to tender the thanks of the guests both formally at the closing meeting and, more informally, a little earlier during an afternoon reception in the Town Hall given by the Municipality of Copenhagen. The Portuguese delegate, when replying to a speech of welcome from the Burgomaster, took full advantage of this opportunity. Finally, in this connexion the name of Prof. J. L. Myers cannot be forgotten. As one of the general secretaries he has had to work hard behind the scenes for many months past to ensure that the gathering should be the very great success it assuredly was. Members and associates will long remember the second meeting of this Congress held in Copenhagen.

M. C. Burkitt.

\section{The International Astronomical Union}

$\mathrm{T}$ HE sixth triennial meeting of the General Assembly of the International Astronomical Union was held at Stockholm on August 3-10 under the presidency of Prof. E. Esclangon. The meeting was the largest and most representative held so far, with more than four hundred people present, including nearly a hundred from the United States. Germany has so far not seen its way to join the Union, but there were more German astronomers present than on any previous occasion. The local organization under Prof. H. von Zeipel, Prof. B. Lindblad and an indefatigable secretary, Dr. Y. Öhman, was extremely good, and combined with perfect weather to contribute to the complete success of the meeting.

After the opening meeting, when the Union was welcomed by the Minister of Justice, the president of the Royal Swedish Academy of Sciences and the chairman of the Swedish National Academy of Sciences, the Union settled down to the task of discussing the reports of the thirty-one committees through which its work is carried out between meetings.

In addition to the specialist discussions carried on in these separate small bodies, there were arranged this time two symposia with a wider range of interest -one on the formation of bright lines in celestial spectra and one on the problem of galactic structure.

Sir Arthur Eddington presided over the first meeting and the speakers were Prof. H. N. Russell, Dr. H. Zanstra, Prof. D. H. Menzel and Dr. P. W. Merrill. At this meeting, M. B.Lyot showed slides of his direct photographs of the corona and the coronal spectrum secured at the Pic du Midi and also a striking cinema film of movements in prominences taken by direct photography. This aroused such enthusiasm that it had to be shown on a second occasion during the meeting. It included one remark- able instance of an existing prominence being blown up by an uprush of fresh matter from below, numerous instances of matter flowing upwards and still more frequently of matter streaming horizontally or down. wards in striking arch formations. The second symposium was presided over by Prof. Lindblad, and the speakers were Dr. B. J. Bok, Prof. Lindblad, Prof. H. Shapley and Dr. Becker. Dr. Baade's photographs showed what striking advances in photographic sensitivity had been achieved recently in the red.

Both discussions led to useful contributions from other speakers and they formed a valuable innova. tion. It was felt in certain quarters that the symposia and the lavish Swedish hospitality had encroached to some extent on the time usually allotted to the work of the committees, but the excursions, especially that on a steamer in the archipelago of Stockholm, gave ample opportunity for another and very valuable side of the activities of the conferencethe discussions between small groups of colleagues gathered together from all over the world.

Among the resolutions adopted by the Committees and later by the General Assembly, a few may be mentioned as having a field of interest outside too specialist a range. A list of standard notations was agreed to ; arrangements were confirmed for studies on early Egyptian and Russian astronomy and a recommendation adopted that the scientific letters of Sir Isaac Newton should be edited and published. Owing to the failure of the world schemes of longitude determination by radio signals carried out in 1926 and 1933, to show any evidence of longitude variation, it was decided to carry out no further scheme of a similar nature for another ten or twelve years at least. Steps were agreed to for hastening the completion of the catalogue of the Carte du Ciel ; the 